\title{
Haber İçeriğinde Yer Alan Bazı Sözcükler Sektörel İmaj Açısından Olumsuz Algı Yaratabilir mi? Kültür Balıkçılığı Ya da Balık Çiftlikleri
}

\section{Dr. Görkem Dalkıran ${ }^{1 *}$}

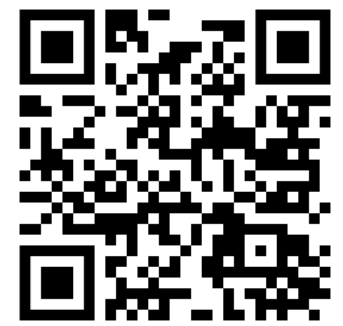

Geliş tarihi: 25.09 .2020

Kabul tarihi: 12.12.2020

\section{Atıf bilgisi:}

IBAD Sosyal Bilimler Dergisi

Sayı: Özel Sayı Sayfa: 639-661

Yıl: 2020

This article was checked by Turnitin. Similarity Index $11 \%$

Bu makalede araştırma ve yayın etiğine uyulmuştur.

${ }^{1}$ Tarım ve Kırsal Kalkınmayı Destekleme Kurumu Kastamonu İl Koordinatörlüğü gorkemdalkiran@gmail.com, ORCID ID 0000-0003-1026-0001

* Sorumlu yazar
ÖZ

Yazılı basında yer alan haber ve köşe yazıları, konu edindiği imgenin topluma aktarılması bakımından şüphesiz en etkili kitle iletişim araçlarından birisidir. $\mathrm{Bu}$ çalışmada son yıllarda gerek üretimde gerekse ihracatta önemli bir ivme kazanmış olan ülkemiz su ürünleri yetiștiriciliği sektörünü konu edinen ulusal gazete haberi içeriklerinin sektörü betimleyen bazı anahtar sözcüklere göre incelenmesi ve haber içeriği eğiliminin anahtar kelimelere göre değișip değişmediğinin irdelenmesi amaçlanmıştır. Çalışma içerik analizi yöntemi ile yürütülmüştür. Bu kapsamda ulusal ölçekte yayınlanan en yüksek tiraja sahip ilk 6 gazetede 2010-2019 yılları arasında çıkan haber ve köşe yazılarının içerikleri "akuakültür ve/veya kültür balıkçılığı" anahtar kelimelerini içeren haberler olacak şekilde birinci grup, "balık çiftliği ve/veya balık çiftlikleri" anahtar kelimeleri içeren haberler olacak şekilde ikinci grup olarak incelenmiştir. Araştırma kapsamında taranan 896 adet haberden ilgili olan 575 adet haber ve köșe yazısı çalıșma kapsamına dahil edilmiş ve haberler; yayımlanma tarihi, kategori, konuyu ele alış biçimi, haber içeriğinin eğilimi ve konu olmak üzere beş kategoride incelenmiştir. Araştırma sonuçlarına göre, su ürünleri yetiştiriciliği sektörü ile ilgili ulusal gazetelerimizde yapılan haberler içeriklerinin ortalama olarak negatiflere kıyasla $(\% 46,26)$ daha çok pozitif eğilimli $(\% 53,74)$ olduğu tespit edilmiștir. Ancak birinci grup haber ve köșe yazılarının çok büyük bir çoğunluğunun $(\% 91,08)$ üretim miktarı ve istihdam, destekleme, ihracat gibi konuların yer aldığı olumlu içerik eğilimine sahip haberler olduğu tespit edilmiş iken, ikinci gruptakilerin büyük bir çoğunluğunun ise $(\% 68,23)$ yaratılan çevre kirliliği ve çevre korunması, lezzet-fiyat-doğallık-kalite, üretim olumsuzlukları, sektör-turizm çatışması gibi konuların yer aldığı olumsuz içerik eğilimine sahip haberler olduğu anlaşılmışır. Yapılan analize göre çalışma kapsamında belirlenen anahtar kelimeler ile haber içeriğinin eğilimi arasında istatistiksel açıdan anlamlı bir ilişki tespit edilmiştir $(p<0,05)$. Çalışma sonucuna göre, "kültür balıkçılığı" ve "akuakültür" sözcüklerinin su ürünleri yetiştiriciliğ yapan işletmeler açısından kamuoyunda olumlu bir simgesel alg1 yaratabileceği, "balık çiftliği" ve "balık çiftlikleri" sözcüklerinin ise olumsuz bir simgesel algı yaratabileceği değerlendirilmektedir. Bu nedenle gazetede yayımlanan haber ve köşe yazıları vasitasıyla toplumda oluşturulan algıların gerek sektördeki işletmeler ve gerekse devlet tarafından sektörel imaj perspektifinde ele alınması gerektiği ve bu hususun yönetilmesi gereken bir başka unsur olduğu göze çarpmaktadır

Anahtar Kelimeler: Kültür balıkçılığı, Balık çiftliği, İçerik analizi, Haber, Köşe Yazıs1 


\section{Can Some Words in News Content Create Negative Perception in terms of Sectoral Image? Aquaculture or Fish Farms}

\section{Dr. Gorkem Dalkiran ${ }^{{ }^{*}}$}

First received: 25.09 .2020

Accepted: 12.12 .2020

\section{Citation:}

IBAD Journal of Social Sciences Issue: Special Issue Pages: 639-661 Year: 2020

This article was checked by Turnitin. Similarity Index 11\%

1 Agriculture and Rural Development
Support Institution, Provincial
Coordination Unit for Kastamonu,
Turkey,
ORCID ID 0000-0003-1026-0001

* Corresponding Author

\begin{abstract}
News and columns in print media are one of the most efficient forms of mass media in terms of transferring its ideas to society. In this study, the aim was to examine news content mentioning the Turkish aquaculture sector, which has recently gained acceleration in production and export, in national newspapers based on some keywords depicting the sector, and to research whether or not the tendency of news content has changed depending on the keywords. The study has been performed with content analysis. For this purpose, the content of news and columns published between 2010 and 2019 in the highest circulation national newspapers were searched with two groups. The first group involved news and column rankings resulting from "aquaculture and/or culture fisheries" keywords, while the second group involved rankings based on "fish farm and/or fish farms" keywords. 575 of 896 news and columns were included as samples. News related to Turkey's aquaculture sector was researched based on five different categories: publishing date, category, approach, the tendency of news content and subject. According to the results of this study, it is found that the aquaculture sector has been averagely portrayed with more positive information $(53,74 \%)$ than negative $(46,26 \%)$ in Turkish newspapers. But it has also been demonstrated that a clear majority $(91,08 \%)$ of the first group has a positive content tendency, having subjects such as production quantity, employment, support and exports. Conversely, the second group generally has a negative content tendency $(68,23 \%)$ having subjects such as environmental pollution and environmental protection, taste-price-naturality-quality and sector-tourism conflict. According to statistical analysis, it has been determined that there is a statistically significant relationship between keywords and the tendency of news content $(\mathrm{p}<0,05)$. It can be said thanks to the findings that "aquaculture" and "culture fisheries" keywords can create a positive symbolic perception in public opinion for the sector, while "fish farm" and "fish farms" can create negative perceptions. Thus, this study has drawn attention to the fact that perceptions of society created by the news and columns in media are another factor that needs to be considered and managed by both businesses and government in terms of the sectoral image perspective.
\end{abstract}

Keywords: Aquaculture, Fish farm, Content analysis, News, Columns 


\section{INTRODUCTION}

Human beings have made an effort to fulfill food requirements in order to maintain life since their existence on earth. This effort, occurring first in the form of hunter-gatherers, has transformed to a new dimension along with the cultivation of some plants and animal species. The transformation known as the agricultural revolution has led to social changes, and man has made permanent settlements and civilizations by abandoning nomadic lifestyles. This historical adventure beginning almost twelve thousand years ago has continued with strategical importance for meeting food requirements, and is likely to continue in the future as well (Harari, 2018, p. 60-89).

Today, agriculture is one branch of activity which may define a national economy. Modern agriculture has maximized efficiency so that the highest income may be obtained per unit area thanks to advancements in science and technology and the use of innovative production techniques. In this way, after fulfilling self-requirements, countries have found opportunities to export products in which they specialize, and agriculture has become a business line contributing to the economy for some countries (Dogan, Arslan, \& Berkman, 2015, p. 31).

However, the prevalence of intensive production techniques has led to some disputations. There are commonly debated issues from using antibiotics in agricultural production to genetically modified organisms, from hormonal food to environmental problems created by agricultural facilities. While pesticide pollution is used to combat weeds and illness, chemical manure pollutions and irrigation-based problems are the most pervasive environmental issues in vegetative production; manure management, pollution, waste of hatcheries and slaughterhouses are seen as environmental problems that need to be solved by businesses in animal production. (Parlakay, Çelik, \& Kiziltug, 2015, p. 21-22; Yibar \& Soyutemiz, 2013, p. 98).

As we are faced with the necessity to meet our nutritional needs in order to sustain our lives, an important question that needs to be asked is how these problems that arise from production techniques can be managed. Hereby some concepts have come into prominence such as safe food, sustainable agriculture, and organic production. Although businesses or government seek to make production safe, sometimes they fail to break negative public perceptions. In this way it brings about both a negative climate for investments and affects the economy negatively by reducing consumer demand.

It should be recalled that demand of chicken and its products decreased after the emergence of the avian flu in Turkey in 2005. It was estimated that the sector turned a loss of $€ 200$ million just 3 months after the outbreak (Caki, 2007, p. 184). The producers, who felt these economic losses most severely, broadcasted advertisements via the Healthy Chicken Information Platform about consuming chicken produced hygienically and safely without any harm to public health. A reputable journalist who garnered public trust throughout his career appeared in these advertisements, and thus the ad was persuasive while conveying sincerity. There was a pervasive public opinion before the avian flu concerning the fact that chickens produced in integrate facilities were unhealthy because they had been fed artificial feed and grown in short periods of time, and it was stated that it were serious increment chicken consumption along with ads was placed on media. It was expressed in some studies that according to weekly results poultry consumption extended 14,5 times after ads, reaching its highest point compared to any point in the past (Tugcu, 2006, p. 73).

As seen in the example above, it is so clear to see the magnitude of mass media's effects on consumer demand both negatively and positively. Therefore, one of the most effective instruments in shaping public perception for any industry is mass media. Thusly it is declared that the role of shaping public opinion and behavior of mass media has been accepted widely, and in order to understand this, it is important, first, to understand the content of messages that are presented to the public in the news (Amberg \& Hall, 2008, p. 143).

Media instruments, which have been introduced to us before or in the $21^{\text {st }}$ century, have a function such as entertaining, giving information and news to the public, and have contributed to learning and the education of people as well. Despite a belief that mass media may have a limited effect on people's opinions and attitudes, it is said that as a result of its informational feature it affects cognitive phenomena 
such as understanding, perceiving and comprehension of imaginative events (Tokgoz, 1984, p. 25). Additionally, it can be stated that creating a public perception is related to and depends on mass media since it brings up certain issues to the agenda (Gokce, 1996, p. 170).

Mass media can be categorized as printed, broadcasted and electronic media. Nowadays the most effective and important instrument of mass media is the internet. Indeed many mass media instruments, even including newspapers, have provided the opportunity for anyone to reach any information easily and quickly on internet (Erer, 2013, p. 25).

It is a fact that there is positive or negative public perception for the aquaculture industry and aquaculture products, as with other food production methods. Recently there has been more research regarding some issues like public opinion of aquaculture products and the effects on purchasing decisions or consumers' beliefs, or the acceptance of the aquaculture industry in social environments (Katranidis, Nitsi, \& Vakrou, 2003; Sayg1, Saka, Firat, \& Katagan, 2006; Fernández-Polanco \& Luna, 2012). In this study, the aim is to examine news published in national newspapers in Turkey related to the aquaculture industry gathering acceleration and supplying half of fisheries production of Turkey in terms of some keywords that are used for description of the industry, and to evaluate whether content of the news creates a negative perception in terms of sectoral image. It is done by determining whether news content that has a high impact for molding public opinion has a negative tendency or positive tendency in terms of these keywords.

\section{CONCEPTUAL FRAMEWORK}

\section{Perception and Its Types}

The dictionary meaning of perception reproduced from the Latin words perceptio is stated as "a belief or opinion, often held by many people and based on how things seem". Perception in philosophy, psychology and conceptual science is defined as the process of providing to be understood and awareness of emotional information. In a word, perception is actually our experience in the world around us, and it includes the process of both describing an environmental stimulant and of responding to it. Perception allows for identifying and describing information received from five sensory organs (sight, hearing, touch, smell and taste), then giving meaning by evaluating them (Qiong, 2017, p. 18).

In the perceiving process, people first communicate with their environment via his/her sense organs. Only considered stimulants, which are emitted from our environment by the thousands, have been associated with previous experiences and achievements. Information is transmitted to the brain and the thinking process related to perception begins. In other words, the perceiver decides how he/she judiciously identifies to sensory messages, when he/she experiences a stimulant. If it is explained in the framework of analysis-synthesis theory, it can be said that the perceiver who experiences the stimulant first develops a hypothesis regarding the stimulant in the light of contextual factors, then he/she compares it with schemata in his mind. The perceiving process can be shaped depending on a person's value judgements, goals and targets, requirements, cultures, knowledge levels, and previous experiences (Kayaoglu, 2013, p. 27; Ozsalmanli \& Pank, 2013, p. 51).

\footnotetext{
${ }^{1}$ https://dictionary.cambridge.org/ Erişim tarihi:17.07.2020
} 
Figure 1: Process of Perceiving

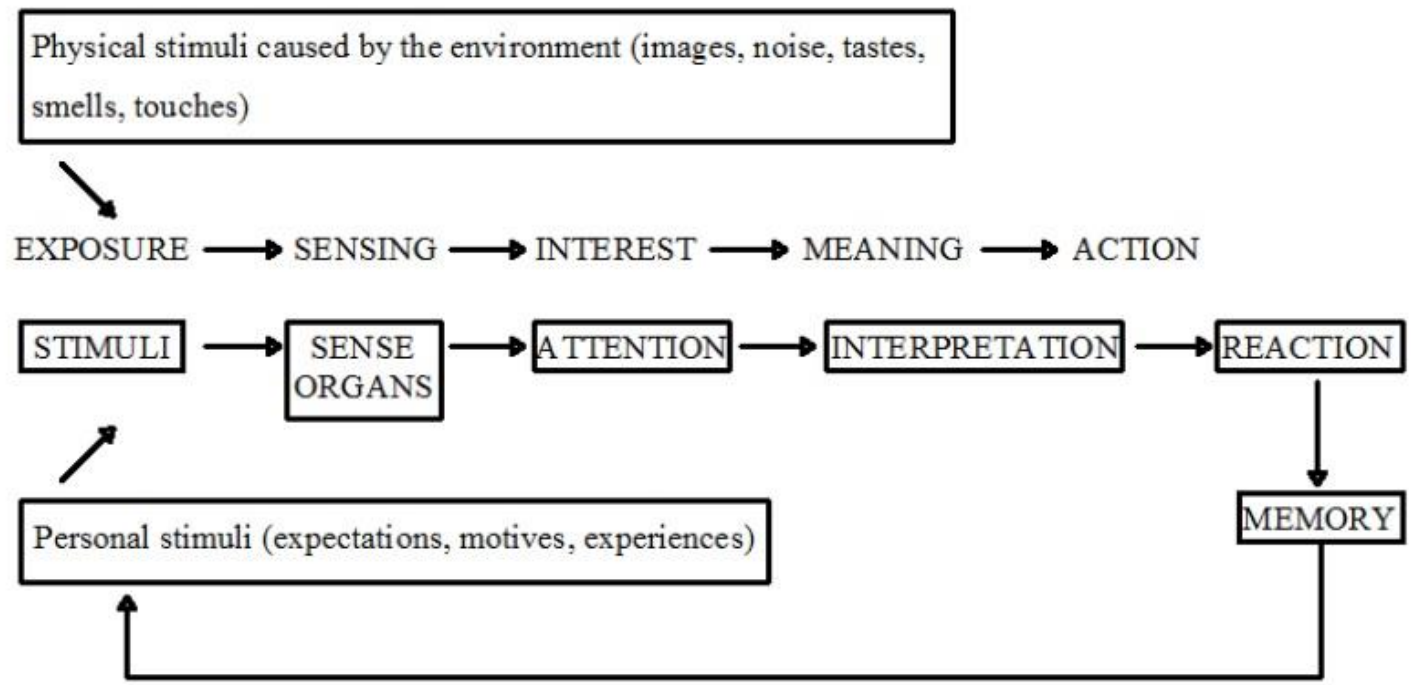

Resource: Kaymaz \& Sungur, 2015, p. 270

People process information received from stimulants in his/her environment via his/her senses by perceiving, and result, perception occurs. Perceptions can create or destroy value in the mind. In this way, the meaning of perceived things can change at certain periods for a person or can be re-identified. Moreover, in the perceiving process a person reaches a result by evaluating current and previous experiences. Since some variables such as a person's current requirements, hopes, experiences and culture are important, the types of perception can simply be classified as symbolic perception, visual perception, sensual perception and selective perception (Tunc \& Atilgan, 2017, p. 230).

Symbolic Perception: Humans have always received sensory information about intangible-tangible objects. Fictitious parts of these perceptions can be portrayed within a symbolic dimension. It can also lead a person throughout a mental process in order to be able to have an understanding of symbolic wholeness. All or one of many things such as gesticulation, mimic, tone of voice, emphasis on words, lapel pin, clothes etc. has created a symbolic perception model (Fidan \& Yetis, 2018, p. 164).

Visual Perception: Many important parts of information are transmitted to our brain via the organ of sight. Visual perception is described as "the ability of recognition and separation of visual stimuli, and transcription of it by means of connecting with previous experiences". In visual perception, a person screens, classifies, interprets and generalizes visual stimuli received with his/her eyes. Therefore, visual perception is related to comprehending visual features of objects (Beyoglu, 2015, p. 336).

Sensual Perception: Sensual perception is generally psychological, and can be stated as the degree of being impressed by ones's emotion in the perceiving process. The current emotional structure of a person can shape his/her perception. However, it is sometimes seen that different people have different perceptions, even when the stimulants are the same (Sara \& Kirikci, 2018, p. 4538).

Selective Perception: In selective perception, which is worded as perceptual selectivity, an event or phenomenon is perceived by focusing on differences such as requirements, values and hopes, physiological features, education and the beliefs of a person since it is not possible that a person can receive all stimuli in their environment (Cita \& Kececioglu, 2015, p. 25).

Although there are numerous factors affecting the perceiving process of a person, it can generally be said that some of these are motivation, learning, specializing and social infrastructure (Otara, 2011, p. 22).

\section{Perception Management}

"Senses" received from stimulants in external environments transform to "perception" by taking a shape in a person's mind, the resulting process described as "perceiving". Thus, perception management 
is dependent on the basis of motivating people voluntarily by affecting this process. While perception management is practiced for directing the target audience in line with certain interests, it is used for purchasing a product or services or persuading individuals as well (Hamzacebi \& Yozgat, 2019, p. 54).

Perception management first arises as a concept used for improving the acceptableness of US foreign and domestic policies, and is expressed as "spreading or stopping of selected information by impressing to emotion, thinking, goal, logic, intelligence systems and their leader, and directing to target behaviors and thoughts in line with hopes of targeter as a result of this". When viewed from this aspect, although it is thought to bear a resemblance to propaganda where providing messages are domineeringly delivered to audiences, in terms of goals and results, perception management actually differs from propaganda with its features such as involving bidirectional communication process with interaction, shaping messages based on the receiver's profile, and providing stimulants that change behavior and attitude (Ceng, 2018, p. 667).

Perception management have gained importance for several organization in the information age. It may be used as an instrument by countries, governments, security agencies, institutions and organizations, and ultimately businesses (Bakan \& Kefe, 2012, p. 24).

Businesses and organizations use perception management as a practice of public relationship, referred to as communication management, taking a managerial approach of prioritizing social values, habits and emotions in order to manage and change people's perception. This approach can be summarized as "Think globally, act locally" (Erbay \& Aslan, 2019, p. 500).

While perception management studies generally investigate how perceptions of external stakeholders are managed, inter-organizational perception management studies are also highly important for realizing future goals of the organization, understanding and representing organizational identity in order to develop organizational effectiveness (Halderen, 2007, p. 24).

The acceptability of products or services served by businesses, occurring from positive perception, and more importantly, the sustainment of it can be possible with perception management. It is thought that organizational perception management includes four components: (1) perception of the organization, (2) actions or "tactics", (3) spokespersons and (4) audiences (Elsbach, 2003, p. 300). Briefly, organizational perception management includes a process where perceptions of all internal and external stakeholders are considered.

Perception management, which takes the shape of public relations instruments by businesses or organizations, has a close relationship with organizational reputations and organizational images. Thus, it is appropriate to first describe these notions.

\section{Organizational Reputation}

Organizational reputation is the whole of values which imprints in the audience's mind that has relationship with any organization and can be interpreted as good or bad. It is related to the organization's past as it is in relationship with value judgements related to what businesses should do or should not do, and to beliefs about what is expected from the organization in the future. Even though organizational reputation is an intangible concept, it is still accepted as a strategic source that would create competitive advantages against competitors (Alniacik, Alniacik, \& Genc, 2010, p. 95-96; Lange, Lee, \& Dai, 2011, p. 155).

It is stated that organizational reputation interacts with the name and image of the organization. It can be also said that the organizational reputation arises from the whole of various images which occurs, interpreting expectations of public opinion for actions and plans of an organization (Ural, 2002, p. 84).

\section{Organizational Image}

There are various definitions for organizational image in literature. One of them is that organizational image is a product of a multivariate impact creation process which is received from organizations, businesses, several news sources and other stakeholders, and interacts with messages spreading from mouth to mouth (Cek, 2016, p. 104). In other words, organizational image is actually a general impression of belief of public opinion about a business. It is expressed that the organizational image 
starts with emotions of customers and businessmen about the organization, aside from individual evaluation of purchased products (Rahayu \& Zanky, 2018, p. 105).

While reputation is defined as "dynamic barriers that are non-material, has competitive advantages against competitors, and blocks to be imitated" in terms of strategy, it also consists of "activities of a business; expectations and reactions about its actions, products and services; expectations of its future and reflections of its past" in terms of the organization (Bilbil, Sütcü, \& Kiyat, 2013, p. 164). Thereby it is natural that organizations trying to build powerful reputations and images in the competitive environment expect to be perceived positively in society. In order to gain competitive advantages, businesses struggle to maintain a positive organizational image by using organizational and public relations within the frame of perception or reputation management instruments. Besides this, they attach importance to creating an organizational reputation, and sustainment and management of it (Doganci, 2017 , p. 30). The existence of an organizational image depends on both a description of an organization as trustworthy, reputable and valuable by all stakeholders, and a perception that is positive (Unaldi, 2015, p. 101). Thus, organizations should carry out several actions in order to positively build their organizational images in society.

\section{Aquaculture Industry}

Public perception of businesses, which is created by organizational reputation and images, in any sector actually builds the sectoral image of this sector. In this section, the current, past and future state of the Turkish aquaculture industry, the subject on which this study is focused, is addressed.

The industry, which is also referred to as "aquaculture, culture fisheries or farming of aquatic organisms", can be define as "an industrial process of raising aquatic organisms up to final commercial production within properly partitioned aquatic areas, controlling the environmental factors and administering the life history of the organism positively and it has to be considered as an independent from fisheries hitherto". It is expressed by the Food and Agriculture Organization of the United Nations (FAO) that it is the most rapid developing food sector of the world (FAO, 2020). Nowadays, aquaculture products provide more than half of the global fisheries production, and it is known that competitiveness of countries, enhancing their aquaculture productions and developing their export capacity, increases as a result (Dalkiran, 2019, p. 62). Turkey has rapidly kept pace with the global trend of aquaculture production. The sector has balanced to capture production by gaining acceleration especially after the 1990 s with the influence of some factors such as infrastructural developments, qualified human resources and technological advancements. It has similarly reached a point of supplying more than half of total fisheries production of Turkey. According to the data, the Republic of Turkey Ministry of Agriculture and Forestry General Directorate Fisheries and Aquaculture, there are 2.286 aquaculture businesses operated on inland and marine areas, with a total production capacity of 486.786 tons per year (MAF, 2020).

Figure 2. The Change of Turkish Fisheries Production by Years (TSI, 2020)

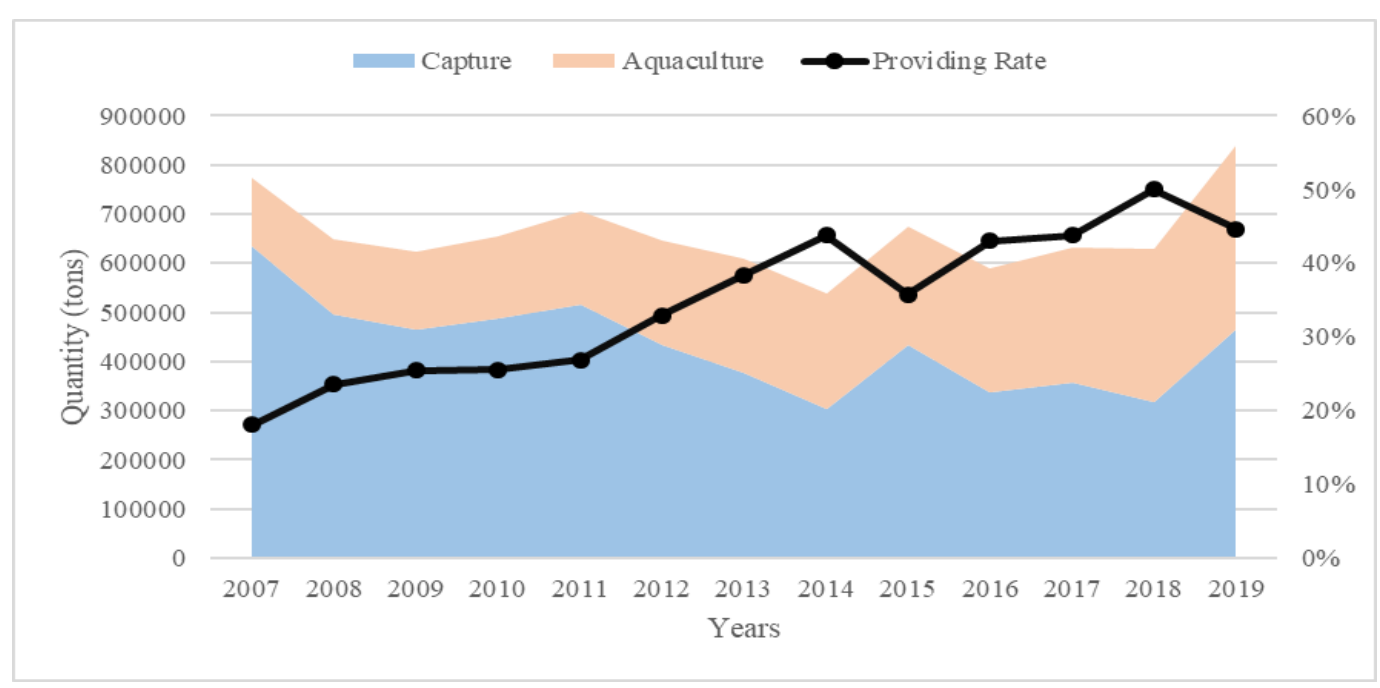


The change of Turkish capture and aquaculture production is shown on Figure 2. Aquaculture production reached 373.356 tons in 2019 by increasing $18 \%$ over the previous year, and supplied $45 \%$ of total production.

Dalkiran (2019, p:83) establishes that there is a statistically strong relationship between aquaculture quantity and the export value of Turkey, and led to an improvement in its competitive power index, which is calculated from revealed comparative advantages (RCA), as aquaculture quantity increases. It is deduced herefrom that the fisheries industry, which is a net exporter in terms of foreign trade, is in direct relation with the aquaculture sector contributing to the international competitive power of Turkey directly. Likewise, if an evaluation of seabass, seabream and rainbow trout species is done, which constitute a major part of total production, it can be clearly seen that Turkey is the leader of the world in terms of seabass and seabream production, and second in rainbow trout.

Since the sector has importance strategically for Turkey and there is a prediction that its quantity may increase in the future, it is believed that it is necessary to understand how public perception of the sector is affected, in order to determine management strategies regarding issues such as improving domestic demand for aquaculture products, setting up facilities in new areas and expanding capacity of current facilities.

\section{Literature Review}

Even though there are some studies performed regarding different issues by using content analysis methodology (Arslan \& Koca, 2006; Yilmaz, 2007; Akyol, 2009; Tasdemir \& Kus, 2011; Erdem \& Gezen, 2014; Yegen, 2014; Pandir, Efe, \& Paksoy, 2015), there is still no examining news related to aquaculture published in Turkish press. Thus, some international studies are given in this section chronologically.

Amberg and Hall (2008) investigated how United States newspaper coverage of farmed salmon fluctuated in the face of scientific information exposed to stories of emerging health and environmental risk in recent years, and which types of purported risks and benefits received the most attention. According to the results of the study, they determined that media attention to farmed salmon focuses more on negative information (e.g.; health and environmental risks) than on positive information (e.g.; health benefits). They expressed that while between 64 and $82 \%$ of text about farmed salmon described human health or environmental risks, only $2-9 \%$ described benefits in the time period between the years 2000-2005. Besides this, it was stated that positive environmental consequences of salmon aquaculture or the possibility that farmed salmon could bring low-cost protein to the public was virtually never mentioned in the news analyzed in the study.

Schlag (2011) utilized media representations, which were investigated in Germany, Norway and the UK over a five-year timeframe (2002-2007), as a proxy for public union. It was indicated that judging by media representations, aquaculture, which was presented as a complex activity comprising health, environmental, economic and socio-organizational dimensions, shares a variety of characteristics with most modern risk, in addition to stating that only economic themes were more often framed in terms of benefits rather than risks. As such, it was determined in the study that aquaculture had an overall negative representation in the media of all these countries. Of course, when looking at the wide-ranging risks highlighted in the media and the dominance of reporting on the industry's risks at the expense of its benefits, it was understandable how and why the industry and its diverse applications might elicit public concerns as the images portrayed by the media analyzed in the study are often negative. It was understood from the study that although the total coverage of the aquaculture sector and farmed fish might be low in comparison to other issues, the public in all three countries had been predominantly exposed to negative information. It was eventually shown that in turn the media's amplification of certain risks might skew public perceptions of farmed fish and the aquaculture industry more generally towards risks.

Feucht and Zander (2016) researched the media coverage of aquaculture in the most widely read German newspapers in the time period from 2008 to 2013 . The results of the study showed that media primarily reported on the aquaculture industry in a positive to neutral tone. While economic benefits of the sector dominated coverage, potential negative aspects of aquaculture received less attention in news analyzed in 
the study. Additionally, recirculated aquaculture systems and organic fish farming came to forefront as eco-friendly practices. Thus, the aquaculture industry in German media was described as being sustainable and practicing good management. It was summarized in the study that the general presentation of aquaculture industry in media was presented as follows: Aquaculture was a dynamic sector with potential for innovation-a sector that was able to connect environmental-friendly practices with local production and quality parameters such as freshness and taste. But aquaculture exhibited some critical issues with respect to the environment and animal welfare.

Forechlich et al. (2017) analyzed the sector by using 1.596 newspaper headlines from 26 developed and 42 developing countries, and they stated that there was a positive trend of general "aquaculture" coverage, while "marine" and "offshore" appeared more negative. It was expressed in the study that developing regions published proportionally more positive than negative headlines than developed countries. As a result of the study, it was suggested that better communication and investigations of the real versus perceived impacts of aquaculture could aid in clarifying the debate about aquaculture, and help support future sustainable growth.

In a study written by Olsen and Osmundsen (2017), how the aquaculture industry was portrayed in Norwegian newspapers was investigated, and how media topics and media framing may influence public opinion was discussed. The analysis in the study showed that the most frequent topics covered in Norwegian newspapers were connected to the environment, aquaculture industry and politics, where the concerns about the environment were dominant within the risk frame. Besides this, it was understood that the negative images portrayed by the media had a strong agenda-setting force, and might skew public opinion to a narrow focus on environmental risks, influencing both the debate's content and regulators' increased emphasis on environmental risks.

Duffy, Rickard and Grosswiler (2019) explored how environmental journalist's routine new value judgements may influence reporting on marine aquaculture in New England. According to results of the study, it was determined that the newsworthiness of aquaculture was largely dependent on how journalists attribute individual news value to a story. Additionally, the results also confirmed how news values and objectivity routines might interact to produce informational bias in environmental new coverage.

\section{METHODOLOGY}

\section{The Aim and Importance of Study}

Production trends in global fisheries has changed into aquaculture. The countries, which are able to improve their production quantity thanks to technological advancements and scientific knowledge, expand their export capacity and even competitiveness. Aquaculture products constitute more than half of global fisheries production. Turkey has kept up with this trend, and its aquaculture production quantity has supplied half of total fisheries production for the past two years. So the export value of Turkey surpassed $\$ 1$ billion in 2019, and the goal for 2023 has been reached four years in advance. Thus, it can be said that the aquaculture industry is of vital importantance for Turkey. However, conflicts encountered with users of the same resources, including the tourism sector, and discussions about its environmental risks can lead to different perceptions by the public in terms of sectoral images of aquaculture industry.

It is clearly stated that the research studies about aquaculture should be performed not only on natural sciences but also on perspectives of social sciences. It is also demonstrated that it is essential to investigate the limited public perception of aquaculture in various states in order to be able to develop risk communication strategies, and that studies should investigate media analysis addressing representations of aquaculture in order to track how the industry is portrayed to the public (Schlag, 2010, p. 842).

The aim of the study is to investigate news mentioning aquaculture industry in national newspapers, which is one of the mass media instruments shaping of public perception, in terms of some keywords depicting the sector, evaluate whether the tendency of the news content has changed depending on the keywords, and to determine how the sector is portrayed in the media. 
It is seen that there is no study yet in literature about the representation of the Turkish aquaculture industry in media. Thus, this study is the first research done on the issue. In addition to this, the study would provide a scientific infrastructure for foreseeing how the keywords, selected by both businesses for forming public opinion and policy makers for determining the industry, can affect public opinion. Moreover, it would be able to be used to evaluate what are the effects of news related to aquaculture on shaping public perception intentionally or unintentionally.

\section{Methodological Approach}

The aim of this study is to examine whether content of news and columns, published in national newspapers on aquaculture, changes in accordance with some keywords depicting the industry. The document analysis method is chosen for this purpose. It is a systematic procedure for reviewing or evaluating printed or electronic documents. As a qualitative research method, document analysis requires that the data be examined and interpreted in order to elicit meaning, gain understanding, and develop empirical knowledge (Bowen, 2009, p. 27). In this way, news and columns published in the first six national newspapers having the highest circulation in Turkey (Sabah, Sözcü, Hürriyet, Posta, Türkiye ve Milliyet) on aquaculture is determined by searching in accordance with the selected keywords in its web pages, and then analyzed with the content analysis method between March - June months of 2020.

The content analysis method can be described as "a research technique that provides to generally examine content systematically in the frame of predetermined classifications". The basis of this analysis method consists of systematically grouping data that is similar to each other with certain concepts. This decoding is able to generally be done with words (Erdem \& Gezen, 2014, p. 24). The words that we encounter in almost every moment in our daily life reflect our opinions, attitudes and emotions, and are transferred from individuals/institutions to individuals/institutions via communication instruments and mutual interactions. The content analysis method is typically used in social sciences in order to expose the meaning of words clearly, objectively, reliably and scientifically (Kocak \& Arun, 2006, p. 21). It is said that the content analysis as a research synthesis plays a crucial role in disseminating research knowledge and in shaping further research, policy, practice, and public perception. It can be classified into three sub-groups: meta-analysis, meta synthesis (thematic content analysis) and descriptive content analysis (Calik \& Sozbilir, 2014, p. 34)

First of all, the keywords were created and grouped with the purpose of searching and the decoding of the news articles and columns in accordance with the study concept. The first group involved "Aquaculture" and "Culture fisheries" (KW1), and the second group was "Fish Farm" and "Fish Farms" (KW2). All groups were searched on web pages of newspapers separately and jointly. In total, 896 pages of news content were searched. Only one repeated news article was incorporated in study, but if the same article was in different newspapers, it was also incorporated in the study because it is possible that these newspapers can be reached by various readers, by evaluating it as different news. News unrelated to the study issue was separated, and content analysis was finally performed on 575 news articles. The articles were examined in five factors, publishing date, category, approach, tendency of news content and subject.

Analyzed data was transformed to a digital format by using a numeric coding system. Coding criteria were constituted similarly to Pandir, Efe and Aksoy's (2015:9) study, and is shown in Table 1 in order to be able to objectively evaluate what paradigm of data coding in there was in this study. Descriptive (i.e. numerical and relationships) and inferential statistics (i.e. comparing meaning) tests were applied to the data set via SPSS V.23 package program. When deciding which inferential statistical method should be used, normality distribution of data was considered, and tests such as ANOVA, t-test, chi-square and correlation were used. 
Table 1. The Coding Criteria of Data

\begin{tabular}{|c|c|c|}
\hline Study Factors & Coding & Criteria \\
\hline Publishing date & $\begin{array}{l}\text { The years between } 2010- \\
2019\end{array}$ & Annually \\
\hline \multirow{2}{*}{ Keywords } & $\begin{array}{l}\text { Aquaculture and/or Culture } \\
\text { Fisheries (KW1) }\end{array}$ & Taking part in text \\
\hline & $\begin{array}{l}\text { Fish Farm and/or Fish Farms } \\
\text { (KW2) }\end{array}$ & Taking part in text \\
\hline \multirow{2}{*}{ Category } & News (1) & $\begin{array}{l}\text { A whole of text published in newspaper, } \\
\text { its supplement or its section, and written } \\
\text { for giving information, and that its writer is } \\
\text { known or not }\end{array}$ \\
\hline & Columns (2) & A whole of text written by a columnist \\
\hline \multirow{2}{*}{ Approach } & Directly (1) & $\begin{array}{l}\text { If the all content of news or columns are } \\
\text { related to aquaculture. }\end{array}$ \\
\hline & Indirectly (2) & $\begin{array}{l}\text { If only a part of content of news or } \\
\text { columns refers to aquaculture, even though } \\
\text { all of it are not related to the sector }\end{array}$ \\
\hline \multirow{2}{*}{$\begin{array}{l}\text { The tendency of news } \\
\text { content }\end{array}$} & Positive (1) & $\begin{array}{l}\text { If positive sides of the sector (export, } \\
\text { quantity price mechanism, market } \\
\text { regulation) is portrayed in news content }\end{array}$ \\
\hline & Negative (2) & $\begin{array}{l}\text { If negative sides of the sector (tourism } \\
\text { conflict, environmental risks) is portrayed } \\
\text { in news content }\end{array}$ \\
\hline Subject & $\begin{array}{lr}\text { Fish } & \text { consumption, } \\
\text { production, } & \text { export, } \\
\text { environment } & \text { pollution, } \\
\text { environment protect, etc. }\end{array}$ & Central topic/theme of news content. \\
\hline
\end{tabular}

There is a suspicious and cautious approach to qualitative research methods against quantitative methods because it is not possible to determine qualifications with clear and sharp standards. Thus, qualification of the researches performed by using this method is evaluated in accurateness concept. Accurateness is regarded as most basic criteria for evaluation of a study's quality, and it gains its meaning with the scope of concepts such as objectivity, detachment, certainty, and measurability. Therefore, it is expressed if the researcher using qualitative research method places importance to these concepts, and if data collection and analysis process is systematic, regular and controllable, it would help to eliminate to some criticizes about the method (Yasar, 2018, p. 57). Since qualitative method is used in this study, it is constituted a test in purpose of evaluating of meaning in a news content within the framework of principle of objectivity, and confirming to content analysis-coding approach aimed at data set. For this purpose, a pilot study is conducted between July 6-13, 2020. 575 news analyzed in the study were regarded as target population, and 85 news were sampled with simple random sampling method ( $d=0,05$ and $10 \%$ sampling error). Web pages' link of sample news were sent to 5 person who have graduate and undergraduate level on various occupation groups. It was requested to evaluate approach, tendency of the news content and subject of news from them, by telling what this study was aimed. It was not seen other factors (publishing date and category) as necessary to send them due to the fact that it was in acceptable qualification for everyone. Evaluating received from persons were coded with same system and transferred to digital platform, and compared to study's data. T-test results performed to comparing is shown Table 2 as follow.

Table 2. T-test results of evaluating the study and persons

\begin{tabular}{|c|c|c|c|c|c|}
\hline \multirow{2}{*}{ Factors } & \multicolumn{2}{|c|}{ Levene Statistics } & \multicolumn{3}{|c|}{ t-test } \\
\cline { 2 - 6 } & $\mathbf{F}$ & $\mathbf{p}$ & $\mathbf{t}$ & $\mathbf{d f .}$ & $\mathbf{p}$ \\
\hline Approach & 3,46 & 0,06 & $-1,39$ & 168 & 0,17 \\
\hline Tendency of News Content & 0,07 & 0,79 & 0,15 & 168 & 0,88 \\
\hline Subject & 4,95 & 0,03 & 0,79 & 165,71 & 0,43 \\
\hline
\end{tabular}


As we can see from Table 2, according the t-test results, there is no statistically significant difference evaluations between study and persons $(p>0,05)$. Therefore, it is confirmed that the analyzed data in the study is objectively, verifiable and repeatable.

\section{Limitations and Boundaries of the Study}

The study is bounded with the years between 2010-2019 and first six newspapers having highest circulation in Turkey. On the other hand, since searching news with selected keywords has been done on web pages of newspapers by using themselves' search engine, the study is also limited with the searching-scanning algorithm of those web pages.

\section{Research Questions and Hypotheses of the Study}

Since media plays an important role in setting public perception, it is significant that understanding how aquaculture industry is portrayed in national press. There are 3 questions and 7 hypotheses in this study. There are as follow:

(Q1): Does the using keywords in news content change by year and by newspaper?

$\mathrm{H}_{1}$ : Change of keywords by years is difference significant statistically.

$\mathrm{H}_{2}$ : Change of keyword by newspapers is difference significant statistically.

(Q2): Does the tendency of news content change by year and by newspaper?

$\mathrm{H}_{3}$ : Change of tendency of news content by years is difference significant statistically.

$\mathrm{H}_{4}$ : Change of tendency of news content by newspapers is difference significant statistically.

(Q3): Does the tendency of news content change as positively or negatively by keywords, by news category, and by news approach?

$\mathrm{H}_{5}$ : There is a statistically significant relationship between tendency of news content and keywords.

$\mathrm{H}_{6}$ : There is a statistically significant relationship between tendency of news content and news category.

$\mathrm{H}_{7}$ : There is a statistically significant relationship between tendency of news content and news approach.

\section{Results}

\section{Descriptive Statistics}

The circulation numbers of national newspaper of Turkey in first quarter of 2020 (12 weeks between January $6^{\text {th }}$ and March $28^{\text {th }}$ ) is shown in Table 3 as follow.

Table 3. The circulation number of national newspapers of Turkey in first quarter of $2020^{2}$

\begin{tabular}{|c|c|c|c|c|c|}
\hline No & Newspaper & January & February & March & First Quarter \\
\hline 1 & Sabah & 971.292 & 974.216 & 929.879 & 2.875 .387 \\
\hline 2 & Sözcü & 967.482 & 974.438 & 912.375 & 2.854 .295 \\
\hline 3 & Hürriyet & 863.185 & 857.586 & 820.578 & 2.541 .349 \\
\hline 4 & Posta & 650.922 & 653.421 & 608.906 & 1.913 .249 \\
\hline 5 & Türkiye & 529.179 & 538.712 & 533.149 & 1.601 .040 \\
\hline \multirow[t]{3}{*}{6} & Milliyet & 502.205 & 502.159 & 496.520 & 1.500 .884 \\
\hline & Others $^{3}$ & 3.071 .039 & 3.128 .137 & 2.913 .505 & 9.112 .681 \\
\hline & Total & 7.555 .304 & 7.628 .669 & 7.214 .912 & 22.398 .885 \\
\hline
\end{tabular}

As it is seen from Table 3 that total circulation number of first six national newspapers (13.286.204), which they are included in the study, constitute of $59,32 \%$ of total circulation in first quarter of 2020.

Number of the news, which are reviewed and analyzed for study, is given in Table 4 per newspaper and keywords as follow:

\footnotetext{
${ }^{2}$ www.gazetetirajlari.com, www.medyaajans.com. (Access date: June $29^{\text {th }}, 2020$ ).

${ }^{3}$ It involves in total circulation numbers of newspapers as Takvim, Akşam, Yeni Şafak, Fanatik, Fotomaç, Korkusuz, Yeni Akit, Yeni Asır, Yeni Birlik, Cumhuriyet, Aydınlık, Doğru Haber ve Karar.
} 
Table 4. Number of reviewed $(R)$ and anlyzed $(A)$ news.

\begin{tabular}{lcccccccccc} 
Newspapers & \multicolumn{2}{c}{ Aquaculture } & \multicolumn{2}{c}{ Culture Fisheries } & \multicolumn{2}{c}{ Fish Farm } & \multicolumn{2}{c}{ Fish Farms } & \multicolumn{2}{c}{ Total } \\
& R & A & R & A & R & A & R & A & R & A \\
\hline Sabah & 8 & 3 & 50 & 41 & 55 & 30 & 34 & 19 & 147 & 93 \\
Sözcü & 2 & 2 & 27 & 26 & 30 & 18 & 14 & 5 & 73 & 51 \\
Hürriyet & 12 & 9 & 156 & 121 & 167 & 102 & 87 & 62 & 422 & 294 \\
Posta & 0 & 0 & 5 & 3 & 3 & 2 & 5 & 2 & 13 & 7 \\
Türkiye & 0 & 0 & 0 & 0 & 5 & 3 & 0 & 0 & 5 & 3 \\
Milliyet & 9 & 7 & 1 & 1 & 203 & 83 & 23 & 36 & 236 & 127 \\
\hline Total & $\mathbf{3 1}$ & $\mathbf{2 1}$ & $\mathbf{2 3 9}$ & $\mathbf{1 9 2}$ & $\mathbf{4 6 3}$ & $\mathbf{2 3 8}$ & $\mathbf{2 4 3}$ & $\mathbf{1 2 4}$ & $\mathbf{8 9 6}$ & $\mathbf{5 7 5}$
\end{tabular}

Number of the analyzed news is shown in Table 5 per newspaper and years.

Table 5. Number of analyzed news.

\begin{tabular}{cccccccc} 
Years & Sabah & Sözcü & Hürriyet & Posta & Türkiye & Milliyet & Total \\
\hline 2010 & 3 & 0 & 26 & 1 & 0 & 25 & $\mathbf{5 5}$ \\
2011 & 9 & 0 & 33 & 1 & 0 & 22 & $\mathbf{6 5}$ \\
2012 & 4 & 0 & 19 & 0 & 0 & 27 & $\mathbf{5 0}$ \\
2013 & 23 & 1 & 15 & 2 & 0 & 12 & $\mathbf{5 3}$ \\
2014 & 11 & 1 & 20 & 0 & 0 & 0 & $\mathbf{3 2}$ \\
2015 & 20 & 2 & 45 & 0 & 0 & 4 & $\mathbf{7 1}$ \\
2016 & 1 & 7 & 24 & 0 & 2 & 4 & $\mathbf{3 8}$ \\
2017 & 9 & 18 & 62 & 0 & 0 & 12 & $\mathbf{1 0 1}$ \\
2018 & 7 & 10 & 40 & 2 & 1 & 18 & $\mathbf{7 8}$ \\
2019 & 6 & 12 & 10 & 1 & 0 & 3 & $\mathbf{3 2}$ \\
\hline Total & $\mathbf{9 3}$ & $\mathbf{5 1}$ & $\mathbf{2 9 4}$ & $\mathbf{7}$ & $\mathbf{3}$ & $\mathbf{1 2 7}$ & $\mathbf{5 7 5}$
\end{tabular}

As it is understood from Table 5, it is seen that, according to searching performed with keywords, the years that having most news published related to aquaculture sector are 2015, 2017 and 2018 respectively. The years that fewest news are also 2014 and 2019. The newspaper publishing the most news about issue is Hürriyet, while Türkiye is fewest.

Number of analyzed news is given in Table 6 per newspapers and study factors.

Table 6. Number of analyzed news per study factors

\begin{tabular}{lccccccc}
\multirow{2}{*}{ Newspapers } & \multicolumn{2}{c}{ Category } & \multicolumn{2}{c}{ Approach } & \multicolumn{2}{c}{$\begin{array}{c}\text { Tendency of the } \\
\text { News Content }\end{array}$} & Total \\
& News & Column & Directly & Indirectly & Positive & Negative & \\
\hline Sabah & 86 & 7 & 46 & 47 & 66 & 27 & $\mathbf{9 3}$ \\
Sözcü & 49 & 2 & 21 & 30 & 21 & 30 & $\mathbf{5 1}$ \\
Hürriyet & 246 & 48 & 161 & 133 & 163 & 131 & $\mathbf{2 9 4}$ \\
Posta & 7 & 0 & 5 & 2 & 3 & 4 & $\mathbf{7}$ \\
Türkiye & 3 & 0 & 3 & 0 & 3 & 0 & $\mathbf{3}$ \\
Milliyet & 91 & 36 & 88 & 39 & 53 & 74 & $\mathbf{1 2 7}$ \\
\hline Total & $\mathbf{4 8 2}$ & $\mathbf{9 3}$ & $\mathbf{3 2 4}$ & $\mathbf{2 5 1}$ & $\mathbf{3 0 9}$ & $\mathbf{2 6 6}$ & $\mathbf{5 7 5}$
\end{tabular}

It is understood from Table 6 that $482(83,83 \%)$ of total analyzed news category are news, while 93 $(16,17 \%)$ are column. The newspaper having highest number of column as percental $(28,35 \%)$ is Miliyet, and Hürriyet follows it (16,33\%). It is determined in Posta and Türkiye newspaper that they have no any column involving the keywords. Approach of 324 of analyzed news (56,35\%) are directly to the issue, while $251(43,65 \%)$ are indirectly. Türkiye newspaper is the highest of directly approach as percental (100,00\%), and Milliyet follows it $(69,29 \%)$, while Posta is the lowest $(41,17 \%)$. The highest rate of direct news is in Türkiye newspaper $(100,00 \%)$, and Milliyet follows it $(69,29 \%)$, while the lowest rate is in Posta $(41,17 \%)$. When it is looked to tendency of the news content factor, it is seen that 309 of analyzed news $(53,74 \%)$ have positive tendency, while 266 of news $(46,26 \%)$ have negative coverage. Sabah is the newspaper having highest rate $(70,97 \%)$ of positive coverage, and Hürriyet $(55,44 \%)$ follows it. Conversely, Sözcü is the newspaper having the lowest rate of positive coverage $(41,18 \%)$.

The news analyzed in this study are categorized as subject categories and shown in Table 7. According to this, it is seen that $194(91,08 \%)$ of news content involving first keyword group (KW1) have positive tendency, while only $19(8,92 \%)$ are negative. The news having positive tendency mostly emphasize to 
several subject such as production quantity-employment $(29,38 \%)$, sector supports $(26,29 \%)$, export value $(20,10 \%)$, whereas others negative tendency underline to taste-price-naturality-quality $(36,84 \%)$ and environment pollution-environment protection $(36,84 \%)$. On the other hand, only $115(31,77 \%)$ of news content involving second keyword group (KW2) have positive tendency, while $247(68,23 \%)$ are negative. These positive news involves in the subject such as production quantity-employment $(55,65 \%)$, entrepreneurship-investment $(11,30 \%)$ and export $(7,83 \%)$, whereas negatives lay weight on generally environment pollution-environment protection $(81,38 \%)$, tourism conflict $(6,07 \%)$ and ecosystem deterioration $(4,45 \%)$.

Table 7. Number of analyzed news by subject categories

\begin{tabular}{|c|c|c|c|c|c|c|c|}
\hline Keywords & $\mathbf{n}$ & $\begin{array}{c}\text { Tendency } \\
\text { of News } \\
\text { Content }\end{array}$ & $\mathbf{n}$ & $\%$ & Subject & $\mathbf{n}$ & $\%$ \\
\hline \multirow{11}{*}{$\begin{array}{c}\text { Keywords } 1 \\
\text { Aquaculture } \\
\text { and/or Culture } \\
\text { Fisheries }\end{array}$} & \multirow{11}{*}{213} & \multirow{7}{*}{ Positive } & \multirow{7}{*}{194} & \multirow{7}{*}{91,08} & Production Quantity, Employment & 57 & 29,38 \\
\hline & & & & & Support & 51 & 26,29 \\
\hline & & & & & Export & 39 & 20,10 \\
\hline & & & & & Science, Technology, Innovation & 15 & 7,73 \\
\hline & & & & & Market Regulation & 13 & 6,70 \\
\hline & & & & & Using of Sources & 7 & 3,61 \\
\hline & & & & & Others & 12 & 6,19 \\
\hline & & \multirow{4}{*}{ Negative } & \multirow{4}{*}{19} & \multirow{4}{*}{8,92} & Taste, Price, Naturality, Quality & 7 & 36,84 \\
\hline & & & & & Pollution, Environment Protection & 7 & 36,84 \\
\hline & & & & & Production, Investment & 3 & 15,79 \\
\hline & & & & & Others & 2 & 10,53 \\
\hline \multirow{15}{*}{$\begin{array}{c}\text { Keywords } 2 \\
\text { Fish Farm and } \\
\text { or Fish Farms }\end{array}$} & \multirow{15}{*}{362} & \multirow{9}{*}{ Positive } & \multirow{9}{*}{115} & \multirow{9}{*}{31,77} & Production Quantity, Employment & 64 & 55,65 \\
\hline & & & & & Support & 2 & 1,74 \\
\hline & & & & & Export & 9 & 7,83 \\
\hline & & & & & Science, Technology, Innovation & 6 & 5,21 \\
\hline & & & & & Using of Sources & 4 & 3,48 \\
\hline & & & & & Eco-friendly production & 4 & 3,48 \\
\hline & & & & & Entrepreneurship, Investment & 13 & 11,30 \\
\hline & & & & & Training, Promotion & 4 & 3,48 \\
\hline & & & & & Others & 9 & 7,83 \\
\hline & & \multirow{6}{*}{ Negative } & \multirow{6}{*}{247} & \multirow{6}{*}{68,23} & Taste, Price, Naturality & 4 & 1,62 \\
\hline & & & & & Pollution, Environment Protection & 201 & 81,38 \\
\hline & & & & & Ecosystem deteriotaion & 11 & 4,45 \\
\hline & & & & & Tourism Conflict & 15 & 6,07 \\
\hline & & & & & Production, Investment & 7 & 2,84 \\
\hline & & & & & Others & 9 & 3,64 \\
\hline \multirow{11}{*}{ Total } & \multirow{11}{*}{575} & \multirow{6}{*}{ Positive } & \multirow{6}{*}{309} & \multirow{6}{*}{53,74} & Production Quantity, Employment & 121 & 39,15 \\
\hline & & & & & Support & 53 & 17,15 \\
\hline & & & & & Export & 48 & 15,53 \\
\hline & & & & & Science, Technology, Investment & 21 & 6,80 \\
\hline & & & & & Using of Sources & 11 & 3,57 \\
\hline & & & & & Others & 55 & 17,80 \\
\hline & & \multirow{5}{*}{ Negative } & \multirow{5}{*}{266} & \multirow{5}{*}{46,26} & Taste, Price, Naturality, Quality & 11 & 4,14 \\
\hline & & & & & Pollution, Environment Protection & 208 & 78,20 \\
\hline & & & & & Production, Investment & 10 & 3,75 \\
\hline & & & & & Tourism Conflict & 15 & 5,64 \\
\hline & & & & & Others & 22 & 8,27 \\
\hline
\end{tabular}

\section{Hypothesis Tests}

It is firstly controlled whether data is normal distribution or not in order to confirm to occurred hypothesis what statistic method should be used. For this purpose, it is performed normality test by calculating skewness and kurtosis parameters of data which are used oftenly in social sciences studies. Results are shown in Table 8. 
Table 8. Normality Test of Data of Variables and Standart Errors

\begin{tabular}{lcccc}
\multicolumn{1}{c}{ Variables } & $\begin{array}{c}\text { Skewness } \\
\text { Parameter }\end{array}$ & S.E. & $\begin{array}{c}\text { Kurtosis } \\
\text { Parameter }\end{array}$ & S.E. \\
\hline Years & $-0,18$ & 0,10 & $-1,32$ & 0,20 \\
Keywords & $-0,54$ & 0,10 & $-1,72$ & 0,20 \\
Newspaper & 0,55 & 0,10 & $-0,66$ & 0,20 \\
Category & 1,84 & 0,10 & 1,40 & 0,20 \\
Approach & 0,26 & 0,10 & $-1,94$ & 0,20 \\
Tendency & 0,15 & 0,10 & $-1,98$ & 0,20 \\
\hline
\end{tabular}

According to Tabachnick and Fidell (2013), it is possible to say if skewness and kurtosis parameters are between $-1,5<\mathrm{x}<1,5$, data distribution is normal. As we can see from Table 8, since either parameters for Years and Newspapers variables are in this interval, it is understood that distribution of only these variables is normal.

Spearman correlation analysis has been performed to understand whether relationships of research variables with each other are significant statistically or not, and to determine what is direction of correlation. Results is given in Table 9.

Table 9. Spearman Corelation Analysis Result for Variables $(n=575)$

\begin{tabular}{|c|c|c|c|c|c|c|}
\hline & Newspaper & Publishing Date & Category & Keywords & Approach & Tendency \\
\hline Newspaper & 1,00 & & & & & \\
\hline $\begin{array}{c}\text { Publishing } \\
\text { Date }\end{array}$ & $-0,21^{* *}$ & 1,00 & & & & \\
\hline Category & $0,19^{* *}$ & $-0,25^{* *}$ & 1,00 & & & \\
\hline Keywords & $0,30^{* * *}$ & $-0,11^{*}$ & $0,26^{* *}$ & 1,00 & & \\
\hline Approach & $-0,16^{* *}$ & $0,09^{*}$ & $-0,02$ & $-0,31^{* *}$ & 1,00 & \\
\hline Tendency & $0,14^{* *}$ & $-0,05$ & $0,23^{* *}$ & $0,57^{* *}$ & $-0,13^{* *}$ & 1,00 \\
\hline
\end{tabular}

There are statistically significant and middle level positive correlation between keywords and tendency of news content variables $(\mathrm{p}<0,01)$. Besides of this, there are also statistically significant but low-level correlation among other variables $(\mathrm{p}<0,05, \mathrm{p}<0,01)$, as we can see from Table 9 .

The chi-square test of independence has been performed to examine whether keywords changes and tendency of news content by publishing date, and or not. Results are shown in Table 10 and Table 11.

Table 10. The relationship between keywords and publishing date

\begin{tabular}{lccccccccc} 
& \multicolumn{9}{c}{ Keywords } \\
Years & \multicolumn{2}{c}{ KW1 } & \multicolumn{2}{c}{ KW2 } & \multicolumn{2}{c}{ Total } & \multirow{2}{*}{$\mathbf{X}^{\mathbf{2}}$} & sd & p \\
\cline { 2 - 7 } & $\mathbf{n}$ & $\mathbf{\%}$ & $\mathbf{n}$ & $\mathbf{\%}$ & $\mathbf{n}$ & $\mathbf{\%}$ & & & \\
\hline $\mathbf{2 0 1 0}$ & 10 & 18,18 & 45 & $\mathbf{8 1 , 8 2}$ & 55 & 100 & & \\
$\mathbf{2 0 1 1}$ & 11 & 16,92 & 54 & $\mathbf{8 3 , 0 8}$ & 65 & 100 & & \\
$\mathbf{2 0 1 2}$ & 9 & 18,00 & 41 & $\mathbf{8 2 , 0 0}$ & 50 & 100 & & \\
$\mathbf{2 0 1 3}$ & 21 & 39,62 & 32 & $\mathbf{6 0 , 3 8}$ & 53 & 100 & & \\
$\mathbf{2 0 1 4}$ & 20 & $\mathbf{6 2 , 5 0}$ & 12 & 37,50 & 32 & 100 & & \\
$\mathbf{2 0 1 5}$ & 56 & $\mathbf{7 8 , 8 7}$ & 15 & 21,13 & 71 & 100 & 93,21 & & \\
$\mathbf{2 0 1 6}$ & 16 & 42,11 & 22 & $\mathbf{5 7 , 8 9}$ & 38 & 100 & & \\
$\mathbf{2 0 1 7}$ & 35 & 34,65 & 66 & $\mathbf{6 5 , 3 5}$ & 101 & 100 & & \\
$\mathbf{2 0 1 8}$ & 22 & 28,21 & 56 & $\mathbf{7 1 , 7 9}$ & 78 & 100 & & \\
$\mathbf{2 0 1 9}$ & 13 & 40,63 & 19 & $\mathbf{5 9 , 3 7}$ & 32 & 100 & & \\
Total & $\mathbf{2 1 3}$ & $\mathbf{3 7 , 0 4}$ & $\mathbf{3 6 2}$ & $\mathbf{6 2 , 9 7}$ & $\mathbf{5 7 5}$ & $\mathbf{1 0 0}$ & & \\
\hline
\end{tabular}


According to the test results, it is determined that there is statistically significant relationship between keywords taking part of news content and publishing date of the news $(\mathrm{p}<0,05)$. Thus, $\mathrm{H}_{1}$ hypothesis is confirmed.

As it is looked to frequency distribution, it is understood that news involving in "Aquaculture and/or Culture Fisheries" are published especially in 2014 and 2015 years, on the other hand "Fish Farm and/or Fish Farms" keywords of the news are more published in remained years.

Table 11. The relationship between tendency of news content and publishing date

\begin{tabular}{|c|c|c|c|c|c|c|c|c|c|}
\hline \multirow{3}{*}{ Years } & \multicolumn{6}{|c|}{ Tendency of News Content } & \multirow{3}{*}{$X^{2}$} & \multirow{3}{*}{ sd } & \multirow{3}{*}{$\mathbf{p}$} \\
\hline & \multicolumn{2}{|c|}{ Positive } & \multicolumn{2}{|c|}{ Negative } & \multicolumn{2}{|c|}{ Total } & & & \\
\hline & $\mathbf{n}$ & $\%$ & $\mathbf{n}$ & $\%$ & $\mathbf{n}$ & $\%$ & & & \\
\hline 2010 & 19 & 34,55 & 36 & 65,45 & 55 & 100 & & & \\
\hline 2011 & 29 & 44,61 & 36 & 55,39 & 65 & 100 & & & \\
\hline 2012 & 18 & 36,00 & 32 & 64,00 & 50 & 100 & & & \\
\hline 2013 & 35 & 66,04 & 18 & 33,96 & 53 & 100 & & & \\
\hline 2014 & 25 & 78,13 & 7 & 21,87 & 32 & 100 & & & \\
\hline 2015 & 55 & 77,46 & 16 & 22,54 & 71 & 100 & 49,59 & 9 & 0,000 \\
\hline 2016 & 23 & 60,53 & 13 & 39,47 & 38 & 100 & & & \\
\hline 2017 & 54 & 53,47 & 47 & 46,53 & 101 & 100 & & & \\
\hline 2018 & 35 & 44,87 & 43 & 55,13 & 78 & 100 & & & \\
\hline 2019 & 14 & 43,75 & 18 & 56,25 & 32 & 100 & & & \\
\hline Total & 309 & 53,74 & 266 & 46,26 & 575 & 100 & & & \\
\hline
\end{tabular}

According to the test results, it is determined that there is statistically significant relationship between tendency of news content and publishing date of the news ( $\mathrm{p}<0,05)$. Thus, $\mathrm{H}_{2}$ hypothesis is confirmed.

As it is looked to frequency distribution, while it is seen the news having positive tendency are more published between 2013-2017 years, whose negative tendency are more in all remained years. These results are also coherent within Table 10.

One-way ANOVA test is used in order to be able to evaluate whether keywords and tendency of news content changes by newspaper or not. Tamhane post-hoc test is also performed to determine what newspapers are different with each newspaper. Result is given in Table 12 and Table 13.

Tablo 12. ANOVA test and Tamhane post-hoc test results for keywords among newspapers

\begin{tabular}{|c|c|c|c|c|c|c|c|c|}
\hline \multirow{3}{*}{ Newspapers } & \multicolumn{5}{|c|}{ Keywords } & \multicolumn{3}{|c|}{ Test statistics } \\
\hline & \multicolumn{2}{|c|}{$\begin{array}{c}\text { KW1 } \\
\text { Aquaculture and/or } \\
\text { Culture Fisheries }\end{array}$} & \multicolumn{2}{|c|}{$\begin{array}{c}\text { KW2 } \\
\text { Fish Farm and/or } \\
\text { Fish Farms }\end{array}$} & \multirow{2}{*}{$\begin{array}{c}\text { Total } \\
\mathbf{n}\end{array}$} & \multirow[t]{2}{*}{ df } & \multirow[t]{2}{*}{$\mathbf{F}$} & \multirow[t]{2}{*}{$\mathbf{P}$} \\
\hline & $\mathbf{n}$ & $\%$ & $\mathbf{n}$ & $\%$ & & & & \\
\hline Sabah $^{\mathbf{a}}$ & 44 & 69,84 & 49 & 30,16 & 93 & & & \\
\hline Sözcü ${ }^{\mathrm{a}}$ & 28 & 54,90 & 23 & 45,10 & 51 & & & \\
\hline Hürriyet $^{\mathrm{a}}$ & 130 & 44,22 & 164 & 55,78 & 294 & 5 & 16,033 & 0,000 \\
\hline Posta ${ }^{a b}$ & 3 & 42,86 & 4 & 57,14 & 7 & & & \\
\hline Türkiye $^{b}$ & 0 & 0,00 & 3 & 100,00 & 3 & & & \\
\hline Milliyet $^{\mathbf{b}}$ & 8 & 6,30 & 119 & 93,7 & 127 & & & \\
\hline Total & 213 & 37,04 & 362 & 62,96 & 575 & & & \\
\hline
\end{tabular}

\begin{tabular}{|c|c|c|c|c|c|c|}
\hline \multirow{2}{*}{\multicolumn{2}{|c|}{ Newpapers }} & \multirow{3}{*}{$\begin{array}{c}\text { Mean Difference } \\
0,08\end{array}$} & \multirow{3}{*}{$\begin{array}{c}\text { Std. Error } \\
0,09\end{array}$} & \multirow{3}{*}{$\frac{\mathbf{p}}{0,99}$} & \multicolumn{2}{|c|}{ 95\% Confidence Interval } \\
\hline & & & & & \multirow{2}{*}{$\begin{array}{c}\text { Lower Bound } \\
-0,19\end{array}$} & \multirow{2}{*}{$\begin{array}{c}\text { Upper Bound } \\
0,34\end{array}$} \\
\hline Sabah & Sözcü & & & & & \\
\hline & Hürriyet & $-0,03$ & 0,06 & 1,00 & $-0,21$ & 0,15 \\
\hline & Posta & $-0,04$ & 0,21 & 1,00 & $-0,96$ & 0,87 \\
\hline & Türkiye & $-0,47^{*}$ & 0,05 & 0,00 & $-0,63$ & $-0,32$ \\
\hline & Milliyet & $-0,41^{*}$ & 0,06 & 0,00 & $-0,58$ & $-0,24$ \\
\hline \multirow[t]{5}{*}{ Sözcü } & Sabah & $-0,08$ & 0,09 & 0,99 & $-0,34$ & 0,19 \\
\hline & Hürriyet & $-0,11$ & 0,08 & 0,93 & $-0,34$ & 0,12 \\
\hline & Posta & $-0,12$ & 0,21 & 1,00 & $-1,02$ & 0,78 \\
\hline & Türkiye & $-0,55^{*}$ & 0,07 & 0,00 & $-0,77$ & $-0,33$ \\
\hline & Milliyet & $-0,49^{*}$ & 0,07 & 0,00 & $-0,71$ & $-0,26$ \\
\hline Hürriyet & Sabah & 0,03 & 0,06 & 1,00 & $-0,15$ & 0,21 \\
\hline
\end{tabular}




$\begin{array}{lccccc}\text { Sözcü } & 0,11 & 0,08 & 0,93 & -0,12 & 0,34 \\ \text { Posta } & -0,01 & 0,20 & 1,00 & -0,95 & 0,92 \\ \text { Türkiye } & -0,44^{*} & 0,03 & \mathbf{0 , 0 0} & -0,53 & -0,36 \\ \text { Milliyet } & -0,38^{*} & 0,04 & \mathbf{0 , 0 0} & -0,49 & -0,27\end{array}$

Table 12. ANOVA test and Tamhane post-hoc test results for keywords among newspapers (Cont.)

\begin{tabular}{|c|c|c|c|c|c|c|}
\hline \multirow{2}{*}{\multicolumn{2}{|c|}{ Newpapers }} & \multirow{3}{*}{$\begin{array}{c}\text { Mean Difference } \\
0,04\end{array}$} & \multirow{3}{*}{$\begin{array}{c}\text { Std. Error } \\
0,21\end{array}$} & \multirow{3}{*}{$\frac{\mathbf{p}}{1,00}$} & \multicolumn{2}{|c|}{ 95\% Confidence Interval } \\
\hline & & & & & \multirow{2}{*}{$\begin{array}{c}\text { Lower Bound } \\
-0,87\end{array}$} & \multirow{2}{*}{$\begin{array}{c}\text { Upper Bound } \\
0,96\end{array}$} \\
\hline Posta & Sabah & & & & & \\
\hline & Sözcü & 0,12 & 0,21 & 1,00 & $-0,78$ & 1,02 \\
\hline & Hürriyet & 0,01 & 0,20 & 1,00 & $-0,92$ & 0,95 \\
\hline & Türkiye & $-0,42$ & 0,20 & 0,71 & $-1,37$ & 0,52 \\
\hline & Milliyet & $-0,37$ & 0,20 & 0,86 & $-1,30$ & 0,57 \\
\hline \multirow{5}{*}{ Türkiye } & Sabah & $0,47^{*}$ & 0,05 & 0,00 & 0,32 & 0,63 \\
\hline & Sözcü & $0,55^{*}$ & 0,07 & 0,00 & 0,33 & 0,77 \\
\hline & Hürriyet & $0,44^{*}$ & 0,03 & 0,00 & 0,36 & 0,53 \\
\hline & Posta & $-0,43$ & 0,20 & 0,71 & $-0,52$ & 1,37 \\
\hline & Milliyet & 0,06 & 0,02 & 0,06 & $-0,00$ & 0,12 \\
\hline \multirow[t]{5}{*}{ Milliyet } & Sabah & $0,41^{*}$ & 0,06 & 0,00 & 0,24 & 0,58 \\
\hline & Sözcü & $0,49^{*}$ & 0,07 & 0,00 & 0,26 & 0,71 \\
\hline & Hürriyet & $0,38^{*}$ & 0,04 & 0,00 & 0,27 & 0,49 \\
\hline & Posta & 0,37 & 0,20 & 0,86 & $-0,57$ & 1,30 \\
\hline & Türkiye & $-0,06$ & 0,02 & 0,06 & $-0,12$ & 0,00 \\
\hline
\end{tabular}

It is understood from the Table 12 that there is no statistically significant difference among Sabah, Sözcü and Hürriyet newspapers $(\mathrm{p}>0,05)$ for keywords. Similarly, although there is no difference between Türkiye and Milliyet nespapers $(\mathrm{p}>0,05)$, there are differences among Sabah, Sözcü and Hürriyet newspaper $(p<0,05)$. Posta newspaper is also same with these two group newspaper $(p>0,05)$. According to these results, $\mathrm{H}_{3}$ hypothesis is also confirmed.

Table 13. ANOVA test and Tamhane post-hoc test results for tendency of news content among newspapers

Tendency of News Content

Test statistics

\begin{tabular}{|c|c|c|c|c|c|c|c|c|}
\hline \multirow{3}{*}{ Newspapers } & \multicolumn{5}{|c|}{ rendency or News Content } & \\
\hline & \multicolumn{2}{|c|}{ Positive } & \multicolumn{2}{|c|}{ Negative } & \multirow{2}{*}{$\begin{array}{c}\text { Total } \\
\mathbf{n}\end{array}$} & \multirow{2}{*}{ df } & \multirow{2}{*}{$\mathbf{F}$} & \multirow{2}{*}{$\mathbf{P}$} \\
\hline & $\mathbf{n}$ & $\%$ & n & $\%$ & & & & \\
\hline Sabah $^{\mathbf{a}}$ & 66 & 70,97 & 27 & 29,03 & 93 & & & \\
\hline Sözcǘb $^{b}$ & 21 & 41,18 & 30 & 58,82 & 51 & & & \\
\hline Hürriyet $^{\text {ab }}$ & 163 & 55,44 & 131 & 44,56 & 294 & & & \\
\hline Posta ${ }^{\text {abc }}$ & 3 & 42,86 & 4 & 57,14 & 7 & 5 & 5,17 & $\mathbf{0 , 0 0}$ \\
\hline Türkiye $^{c}$ & 3 & 100,00 & 0 & 0,00 & 3 & & & \\
\hline Milliyet $^{\mathbf{b}}$ & 53 & 41,73 & 74 & 58,27 & 127 & & & \\
\hline Total & 309 & 53,74 & 266 & 46,26 & 575 & & & \\
\hline
\end{tabular}

Variables expressed with different superscript in same column are statistically different from each other $(p<0,05)$

\begin{tabular}{|c|c|c|c|c|c|c|}
\hline \multirow{2}{*}{\multicolumn{2}{|c|}{ Newpapers }} & \multirow{3}{*}{$\begin{array}{c}\text { Mean Difference } \\
-0,30^{*}\end{array}$} & \multirow{3}{*}{$\begin{array}{c}\text { Std. Error } \\
0,08\end{array}$} & \multirow{3}{*}{$\begin{array}{c}\mathrm{p} \\
0,01\end{array}$} & \multicolumn{2}{|c|}{ 95\% Confidence Interval } \\
\hline & & & & & \multirow{2}{*}{$\begin{array}{c}\text { Lower Bound } \\
-0,55\end{array}$} & \multirow{2}{*}{$\begin{array}{c}\text { Upper Bound } \\
-0,05\end{array}$} \\
\hline Sabah & Sözcü & & & & & \\
\hline & Hürriyet & $-0,16$ & 0,06 & 0,08 & $-0,32$ & 0,01 \\
\hline & Posta & $-0,28$ & 0,21 & 0,98 & $-1,20$ & 0,64 \\
\hline & Türkiye & $0,29^{*}$ & 0,05 & 0,00 & 0,15 & 0,43 \\
\hline & Milliyet & $-0,29^{*}$ & 0,06 & 0,00 & $-0,48$ & $-0,10$ \\
\hline \multirow[t]{5}{*}{ Sözcü } & Sabah & $0,30^{*}$ & 0,08 & 0,01 & 0,05 & 0,55 \\
\hline & Hürriyet & 0,15 & 0,08 & 0,62 & $-0,09$ & 0,37 \\
\hline & Posta & 0,02 & 0,21 & 1,00 & $-0,88$ & 0,92 \\
\hline & Türkiye & $0,59^{*}$ & 0,07 & 0,00 & 0,37 & 0,80 \\
\hline & Milliyet & 0,01 & 0,08 & 1,00 & $-0,24$ & 0,25 \\
\hline \multirow[t]{5}{*}{ Hürriyet } & Sabah & 0,16 & 0,06 & 0,08 & $-0,01$ & 0,32 \\
\hline & Sözcü & $-0,14$ & 0,08 & 0,62 & $-0,37$ & 0,09 \\
\hline & Posta & $-0,12$ & 0,20 & 1,00 & $-1,06$ & 0,81 \\
\hline & Türkiye & $0,44^{*}$ & 0,03 & 0,00 & 0,36 & 0,53 \\
\hline & Milliyet & $-0,14$ & 0,05 & 0,14 & $-0,29$ & 0,02 \\
\hline
\end{tabular}


Table 13. ANOVA test and Tamhane post-hoc test results for tendency of news content among newspapers (Cont.)

\begin{tabular}{|c|c|c|c|c|c|c|}
\hline \multirow{2}{*}{\multicolumn{2}{|c|}{ Newpapers }} & \multirow{3}{*}{$\begin{array}{c}\text { Mean Difference } \\
0,28\end{array}$} & \multirow{3}{*}{$\begin{array}{c}\text { Std. Error } \\
0,21\end{array}$} & \multirow{3}{*}{$\frac{\mathbf{p}}{0,98}$} & \multicolumn{2}{|c|}{ 95\% Confidence Interval } \\
\hline & & & & & \multirow{2}{*}{$\begin{array}{c}\text { Lower Bound } \\
-0,63\end{array}$} & \multirow{2}{*}{$\frac{\text { Upper Bound }}{1,20}$} \\
\hline Posta & Sabah & & & & & \\
\hline & Sözcü & $-0,01$ & 0,21 & 1,00 & $-0,92$ & 0,88 \\
\hline & Hürriyet & 0,13 & 0,20 & 1,00 & $-0,81$ & 1,06 \\
\hline & Türkiye & 0,57 & 0,20 & 0,37 & $-0,37$ & 1,52 \\
\hline & Milliyet & $-0,01$ & 0,21 & 1,00 & $-0,93$ & 0,91 \\
\hline \multirow[t]{5}{*}{ Türkiye } & Sabah & $-0,29^{*}$ & 0,05 & 0,00 & $-0,43$ & $-0,15$ \\
\hline & Sözcü & $-0,59^{*}$ & 0,07 & 0,00 & $-0,80$ & $-0,37$ \\
\hline & Hürriyet & $-0,44^{*}$ & 0,03 & 0,00 & $-0,53$ & $-0,36$ \\
\hline & Posta & $-0,57$ & 0,20 & 0,37 & $-1,51$ & 0,37 \\
\hline & Milliyet & $-0,58^{*}$ & 0,04 & 0,00 & $-0,71$ & $-0,45$ \\
\hline \multirow[t]{5}{*}{ Milliyet } & Sabah & $0,29^{*}$ & 0,06 & 0,00 & 0,10 & 0,48 \\
\hline & Sözcü & $-0,01$ & 0,08 & 1,00 & $-0,25$ & 0,24 \\
\hline & Hürriyet & 0,14 & 0,05 & 0,14 & $-0,02$ & 0,29 \\
\hline & Posta & 0,01 & 0,21 & 1,00 & $-0,91$ & 0,93 \\
\hline & Türkiye & $0,58^{*}$ & 0,04 & 0,00 & 0,45 & 0,71 \\
\hline
\end{tabular}

As it is understood from Table 13, even though there is no statistically significant difference between Milliyet and Sözcü newspaper for keywords $(p>0,05)$, it is found that Sabah and Türkiye newspapers does show significant difference each other statistically $(p<0,05)$. On the other hand, although Türkiye newspaper is same with all other newspaper, Posta newspaper is different statistically from all of them. According to these results, $\mathrm{H}_{4}$ hypothesis is confirmed.

The chi-square test of is used to determine whether there is statistically relationship between tendency of news content and keywords. Test results is given Table 14.

Table 14. The relationship between tendency of news content and keywords

\begin{tabular}{|c|c|c|c|c|c|c|c|c|c|}
\hline \multirow{3}{*}{ Keywords } & \multicolumn{6}{|c|}{ Tendency of news content } & \multirow{3}{*}{$\mathbf{X}^{2}$} & \multirow{3}{*}{ sd } & \multirow{3}{*}{ p } \\
\hline & \multicolumn{2}{|c|}{ Positive } & \multicolumn{2}{|c|}{ Negative } & \multicolumn{2}{|c|}{ Total } & & & \\
\hline & $\mathrm{n}$ & $\%$ & n & $\%$ & $\mathbf{n}$ & $\%$ & & & \\
\hline KW1 & 194 & 91,08 & 19 & 8,92 & 213 & 100 & & & \\
\hline KW2 & 115 & 31,77 & 247 & 68,23 & 362 & 100 & 189,76 & 1 & 0,000 \\
\hline Total & 309 & 53,73 & 266 & 46,27 & 575 & 100 & & & \\
\hline
\end{tabular}

It is found that there is statistically significant relationship between the variables $(p<0,05)$. According to the test results, $\mathrm{H}_{5}$ hypothesis is also confirmed. As we can see from frequency distribution, $91,08 \%$ of the news involving in first keywords group (Aquaculture and/or Culture Fisheries) have positive tendency, while the only 31,77\% of news involving second keywords group (Fish Farm and/or Fish Farms) are portrayed positively. In other words, the only $8,92 \%$ of the news involving in first keywords group have negative tendency of news content, whereas $68,23 \%$ of the news involving second keywords group have negatively news coverage.

The chi-square test of is used to determine whether there is statistically relationship between tendency of news content and news category. Test results are shown as Table 15.

Table 15. The relationship between tendency of news content and news category

\begin{tabular}{|c|c|c|c|c|c|c|c|c|c|}
\hline \multirow{3}{*}{$\begin{array}{c}\text { News } \\
\text { Category }\end{array}$} & \multicolumn{6}{|c|}{ Tendency of News Content } & \multirow{3}{*}{$\mathbf{X}^{2}$} & \multirow{3}{*}{ sd } & \multirow{3}{*}{ p } \\
\hline & \multicolumn{2}{|c|}{ Positive } & \multicolumn{2}{|c|}{ Negative } & \multicolumn{2}{|c|}{ Total } & & & \\
\hline & $\mathbf{n}$ & $\%$ & $\mathbf{n}$ & $\%$ & $\mathbf{n}$ & $\%$ & & & \\
\hline News & 283 & 58,71 & 199 & 41,29 & 482 & 100 & & & \\
\hline Column & 26 & 27,96 & 67 & 72,04 & 93 & 100 & 29,67 & 1 & 0,000 \\
\hline Total & 309 & 53,74 & 266 & 46,26 & 575 & 100 & & & \\
\hline
\end{tabular}

It is also determined that there is statistically significant relationship between the variables $(p<0,05)$. According to the test results, $\mathrm{H}_{6}$ hypothesis is confirmed. When it is looked frequency distribution, it is understood that $58,71 \%$ of the news in news category have positive tendency while only $27,96 \%$ of columns is positive. But, $41,29 \%$ of the news is portrayed as negatively while $72,04 \%$ of the columns have negative tendency. 
The chi-square test of is used to determine whether there is statistically relationship between approach and the tendency of news content. Test results is shown as Table 16.

Table 16. The relationship between the tendency of news content and approach

\begin{tabular}{|c|c|c|c|c|c|c|c|c|c|}
\hline \multirow{3}{*}{ Approach } & \multicolumn{6}{|c|}{ Tendency of News Content } & \multirow{3}{*}{$\mathbf{X} 2$} & \multirow{3}{*}{ sd } & \multirow{3}{*}{$\mathbf{p}$} \\
\hline & \multicolumn{2}{|c|}{ Positive } & \multicolumn{2}{|c|}{ Negative } & \multicolumn{2}{|c|}{ Total } & & & \\
\hline & $\mathbf{n}$ & $\%$ & $\mathbf{n}$ & $\%$ & $\mathbf{n}$ & $\%$ & & & \\
\hline Directly & 155 & 47,84 & 169 & 52,16 & 324 & 100 & & & \\
\hline Indirectly & 154 & 61,35 & 97 & 38,65 & 251 & 100 & 10,39 & 1 & 0,001 \\
\hline Total & 309 & 53,74 & 266 & 46,26 & 575 & 100 & & & \\
\hline
\end{tabular}

As it is able to interpreted from Table 16, there is statistically significant relationship between the variables $(\mathrm{p}<0,05)$. According to the test results, $\mathrm{H}_{7}$ hypothesis is also confirmed. It is found that $47,84 \%$ of the directly news in approach category have a positive tendency, while only $61,35 \%$ of indirectly news is positive. Additionally, 52,16\% of the directly news in approach category have a negative tendency, whereas only $38,35 \%$ of the indirectly news is published with negative tone.

\section{Discussion and Conclusion}

Aquaculture products would be as important in the near future in the point of quality protein supply. As having a voice in the EU market in terms of sector, Turkey has constituted various strategies oriented improving both production areas and quantity within the expanded global market. However, discussion on particularly both environmental effect of the sector and its level affects to acceptableness in society. In the light of this, it is revealed that public reflections for the sector opens new research areas. So scientists express that scientific researches on aquaculture should be expanded by performing social sciences studies laying on perspectives such as socio-economic structure, sociological impact, etc. as well as natural sciences (Schlag, 2010). When taking into consideration that there are limited study in related literature, from this perspective having done some researches is though that it needs having done some researches from this perspective.

In this study, news and columns published first six national newspapers which have the highest circulation rate in Turkey for 10 years period have been analyzed in terms of keywords depicting the sector, and been searched the answer to the three questions.

It is found that analyzed news in this study have generally positive tone $(n=309,53,74 \%)$ about the sector. It is seen that aquaculture sector has been portrayed in media as negatively in most countries (Amberg \& Hall, 2008; Schlag, 2011; Forechlich, Gentry, Rust, Grimm, \& Halpern, 2017; Olsen \& Osmundsen, 2017; Duffy, Rickard, \& Grosswiler, 2019). In the case of this, when it is compared to the other studies, this result differs from studies in literature on this issue except Feucht and Zander (2016).

According to both correlation analysis and chi-square test, there is statistically significant relationship between keywords and the tendency of news content $(X 2=189,76 \mathrm{p}<0,05, C=0,57 \mathrm{p}<0,01)$. While the news involving in the first keywords group have a positive tendency of news content, having the second keywords group have a negative. Some studies show that the presence of certain sounds in a brand name can alter expectations about even product's taste because there is a systematic relationship between sounds and their perceived meanings (Pathak \& Calvert, 2020, p. 2). When taking into consideration of the role of mass media shaping public perception, in this case it can be deduced that "Aquaculture and/or Culture Fisheries" keywords make a positive symbolic perception on society, whereas "Fish Farm and/or Fish Farms" keyword make a negative as well.

Besides, it is also found that change of keywords by years is difference significant statistically $(p<0,05)$. Similarly, change of the tendency of news content by years and by newspapers is different $(p<0,05)$. It is concluded from this point that news on positive tone, or negative as well, with selected keywords is seen especially some years and some newspaper.

Furthermore, statistically significances of the relationship between news category and tendency of the news content means actually that columnist effects from their bias and writes by emphasizing negative information (pollution and environmental issues, etc.) about the sector, while news focuses largely on 
positive ways (production, employment, export, etc.). This result is similar to Duffy, Rickard and Grosswiler's findings (2019).

Most of the negative news on the sector $(\mathrm{n}=208,78,28 \%)$ subjects on environmental pollution and protection issues. But, a recent study shows that offshore marine aquaculture has a limited effect on the seas directly. Even if organic pollution parameters is highest especially in summer, it is stated that reason of this is that common user of the sources (population grow for tourism, agricultural activities, etc) increases in this season (Türk Çulha \& Karaduman, 2020, p. 6).

All of these results are demonstrated to us that aquaculture sector has been averagely portrayed positive than negative on Turkish newspapers. But there are also shown that selected words used in media can shape public perception on positive way or negative way unintentionally or intentionally. Thus, suggestions of this study of which are determined according to its results can be ranked as follow:

- It would be useful if firms, NGOs or policy makers takes into consideration this issue when they present on the sector to an audience, since public perception about aquaculture can may changes by selected keywords.

- Since it is determined that most of the negative news on the sector focuses more on environmental issues, it is thought that it is better if platforms where telling what environmental effects and pollutants of the sector is, may be occurred by featuring especially eco-friendly production method. Thus businesses reflecting themselves with ecological approach and participating and/or arranging several socio-environmental events may be more competitive than others.

- It would be also beneficial that certain efforts should be made by NGOs, government and leader firm on the sector in order to break the bias, because of the fact that it is understood the tone of columns on aquaculture in newspapers has generally a negative tendency.

- It is eventually suggested that more comprehensive studies should be performed in a multidisciplinary approach such as aquaculture-business-communication perspectives by providing the integration of social and natural sciences all around the country since this study is the first research on this issue.

\section{REFERENCES}

Akyol, A. (2009). Qualitive and quantitive features of newspaper advertising: A content analiysis on automotive advertisements. Seljuk University Journal of Faculty of Letters, (21), 1-27.

Alniacik, E., Alniacik, U., \& Genc, N. (2010). Are percieved importance levels of corporate reputation components affected by demograpich factors? Balikesir University The Journal of Social Sciences Institute, 13(23), 93-114.

Amberg, S., \& Hall, T. (2008). Communicating risks and benefits of aquaculture: A content analysis of US newsprint representations of farmed salmon. Journal of the World Aquaculture Society, 39(2), 143-157.

Arslan, B., \& Koca, C. (2006). An examination of representation of Women athlets-related articles in dailiy newspapers. Hacettepe Journal of Sport Sciences, 17(1), 1-10.

Bakan, I., \& Kefe, I. (2012). The organizational perspective of perception and perception management. Kahramanmaras Sutcu Imam University Faculty of Economics and Administrative Sciences Journal, 2(1), 19-34.

Beyoglu, A. (2015). Perception, visual perception and illusion in art education: An examination in the works of Victoria Vasarely. Trakya University Journal of Social Sciences, 17(1), 333-348.

Bilbil, E., Sütcü, C., \& Kiyat, B. (2013). Research on corporate reputation quotient and brand loyality in telecommunications sector in Turkey. Öneri Journal Contemporary Studies in Social Sciences, 10(39), 163-175.

Bowen, G. (2009). Document analysis as a qualitative research method. Qualitative Research Journal, $9(2), 27-40$. 
Caki, S. (2007). The place and situation of poultry industry in Turkish economy. Ege Academic Review, 7(1), 153-189.

Calik, M., \& Sozbilir, M. (2014). Parameters of content analysis. Education and Science, 39(174), 33-38.

Cek, K. (2016). The effects of corporate images on customers' behavior. The Journal of Public Finance and Finance Articles/Writings, (106), 101-128.

Ceng, E. (2018). A politic analysis on the use of twitter as a perception management vehicle. Journal of Erciyes Communication, 5(4), 663-689.

Cita, K., \& Kececioglu, T. (2015). A research by performance management systems perception of employees. EUL Journal of Social Sciences, VI(II), 19-36.

Dalkiran, G. (2019). A study on international competitiveness position of aquaculture businesses in Turkey. Unpublished Doctorate Thesis, Karabük University Institute of Graduate Program, Karabük.

Dogan, Z., Arslan, S., \& Berkman, A. (2015). Development and problems of agricultural sector in Turkey: A historical outlook. Niğde Univeristy Academic Review of Economics and Administrative Sciences, 8(1), 29-41.

Doganci, M. (2017, Temmuz). A research on the institutional perspectives of the university. Unpuplished Doctorate Thesis, Maltepe University, Institute of Social Sciences, İstanbul.

Duffy, K., Rickard, L., \& Grosswiler, P. (2019). Routine influences on aquaculture news selection: A Q method study with New England journalists. Science Communication, 1-31.

Elsbach, K. (2003). Organizational perception management. Research in Organizational Behavior, 25, 297-332.

Erbay, M., \& Aslan, M. (2019). The effects of social values on perception management. Ulakbilge Journal of Social Sciences, 38, 497-504.

Erdem, B., \& Gezen, T. (2014). The examination of job advertisements for tourism establishments by content analysis method. International Journal of Economics and Business, 10(21), $19-42$.

Erer, S. (2013). Mass media and medical ethics. Journal of Duzce University Health Sciences Institute, $3(3), 24-28$.

FAO (2020). Food and agriculture organization of the United Nations. Retrieved August 10, 2020 from www.fao.org

Fernández-Polanco, J., \& Luna, L. (2012). Factors affecting consumers' beliefs about aquaculture. Aquaculture Economics \& Management, 16(1), 22-39.

Feucht, Y., \& Zander, K. (2016). Aquaculture in German print media. Aquaculture International, 25, $177-195$

Fidan, M., \& Yetis, A. (2018). Perception in health communication: A research on public service announcements (PSA). Journal of Selcuk Communication, 11(2), 159-178.

Forechlich, H., Gentry, R., Rust, M., Grimm, D., \& Halpern, B. (2017). Public perceptions of aquaculture: Evaluating spatiotemporal patterns of sentiment around the World. Plos One, 12(1), $1-18$.

Gokce, O. (1996). Public opinion and mass media. Journal of Social Sciences of the Turkic World, I(Spring), 163-171.

Halderen, M. (2007). Organizational identity expressiveness and perception management. Rotterdam: Erasmus Research Institute of Management RSM Erasmus University.

Hamzacebi, A., \& Yozgat, U. (2019). Role of perception management of tourism sector. International Journal of Management and Administration, 3(5), 51-65. 
Harari, Y. (2018). From animals into gods: A brief history of humankind. (E. Genç, Trans.) İstanbul: Kolektif (Turkish Print).

Katranidis, S., Nitsi, E., \& Vakrou, A. (2003). Social acceptability of aquaculture development in coastal areas: The case of two Greek islands. Coastal Management, 31(1), 37-53.

Kayaoglu, A. (2013). Perception. M. Goregenli, A. Kayaoglu, A. Bilgin, \& F. Curun. (Eds.) Behaviroal Science II, 27. Eskişehir: T.C. Anadolu University.

Kaymaz, K., \& Sungur, M. (2015). The effects of knowledge acquisition levels on perception in art education. Anadolu Journal of Educational Sciences International, (Art Educational Special Issue), 266-281.

Kocak, A., \& Arun, O. (2006). The sampling problem in content analysis studies. Journal of Selcuk Communication, 4(3), 21-28.

Lange, D., Lee, P., \& Dai, Y. (2011). Organizational reputation: A review. Journal of Management, 37(1), 153-184.

MAF. (2020). Ministry of agriculture and forestry general directorate of fisheries and aquaculture, Fisheries statistics. Ankara: Tarım Orman Bak.

Olsen, M., \& Osmundsen, T. (2017). Media framing of aquaculture. Marine Policy, 76, 19-27.

Otara, A. (2011). Perception: A guide for managers and leaders. Journal of Management and Strategy, 2(3), 21-24.

Ozsalmanli, A., \& Pank, C. (2013). Perception management and its importance for ethics in public administration. Journal of Law and Economic Researches, 5(2), 47-61.

Pandir, M., Efe, İ., \& Paksoy, A. (2015). A content analysis on the representation of Syrian asylum seekers in the Turkish press. Marmara Journal of Communication, (24), 1-26.

Parlakay, O., Çelik, A., \& Kiziltug, T. (2015). Environmental issues caused by agricultural production and solution proposals in Hatay province. Journal of Agricultural Faculty of Mustafa Kemal University, 20(2), 17-26.

Pathak, A., \& Calvert, G. (2020). Sounds sweet, sounds bitter: How the presence of certain sounds in a brand name can alter expectations about product's taste. Food Quality and Preference, 83, 1-10.

Qiong, O. (2017). A brief introduction to perception. Studies in Literature and Language, 15(4), 18-28.

Rahayu, F., \& Zanky, M. (2018). The effects of corporate image, users image, and product image towards purchasing interest of Suzuki motorcycle. The First International Research Conferance on Economics and Business. 104-113. KnE Social Sciences.

Sara, O., \& Kirikci, S. (2018). Literature review: Planned behavior theory and behavioral economics. Social Sciences Studies Journal, 4(23), 4534-4548.

Saygi, H., Saka, S., Firat, K., \& Katagan, T. (2006). The consumption of fish and approach to fish culture of public opinion in İzmir central districts. Ege University Journal of Fisheries \& Aquatic Sciences, 23(1-2), 133-138.

Schlag, A. (2010). Aquaculture: an emerging issue for public concern. Journal of Risk Research, 13(7), 829-844.

Schlag, A. (2011). Aquaculture in Europe: Media representations as a proxy for public opinion. International Journal of Fisheries and Aquaculture, 3(7), 158-165.

Tabachnick, B., \& Fidell, L. (2013). Using multivariate statistics. Boston: Pearson.

Tasdemir, A., \& Kus, Z. (2011). The content analysis of the news in the national papers concerning the renewed primary curriculum. Educational Sciences: Theory \& Practice, 11(1), 16-23. 
Tokgoz, O. (1984). The role and importance of mass media in unaware learning. Education and Science, 23-28.

TSI. (2020). Turkish statistical institute fisheries statistics. Ankara: TUIK.

Tugcu, E. (2006). The village imagery created in commercials and the "integrated" chickens produced by avian flu. International and Quarterly Journal of Cultural Studies, 9(71), 71-74.

Tunc, A., \& Atilgan, A. (2017). An administrative understanding on perception: Perception administration. International Journal of Disciplines Economics \& Administrative Sciences Studies, 3(3), 228-238.

Türk Çulha, S., \& Karaduman, F. (2020). The influence of marine fish farming on water and sediment quality: Ildır Bay (Aegean Sea). Environ Monit Assess, 192(8), 528, 1-10.

Unaldi, N. (2015). The importance of reputation in health-care institutions. Journal of Health and Nursing Management, 2(2), 100-111.

Ural, E. (2002). Reputation management as a public relations study creating value. The Journal of Istanbul Commerce University, 83-93.

Yasar, M. (2018, Kasim). Qualitative problem in qualitative research. MSKU Journal of Education, 5(2), $55-73$.

Yegen, C. (2014). The presentation of woman murder news in the internet journalism: Sample of daily "Posta". The Turkish Online Journal of Design, Art and Communication, 4(3), 15-28.

Yibar, A., \& Soyutemiz, E. (2013). Antibiotic use in food-producing animals and possible residual risks. Journal of Veterinery Sciences of Ataturk University, 8(1), 97-104.

Yilmaz, R. (2007). Gender roles in advertisements: A content analysis of the advertisements published in Milliyet newspaper between the years, 1960 and 1990. Journal of Selcuk Communication, 4(4), $143-155$. 